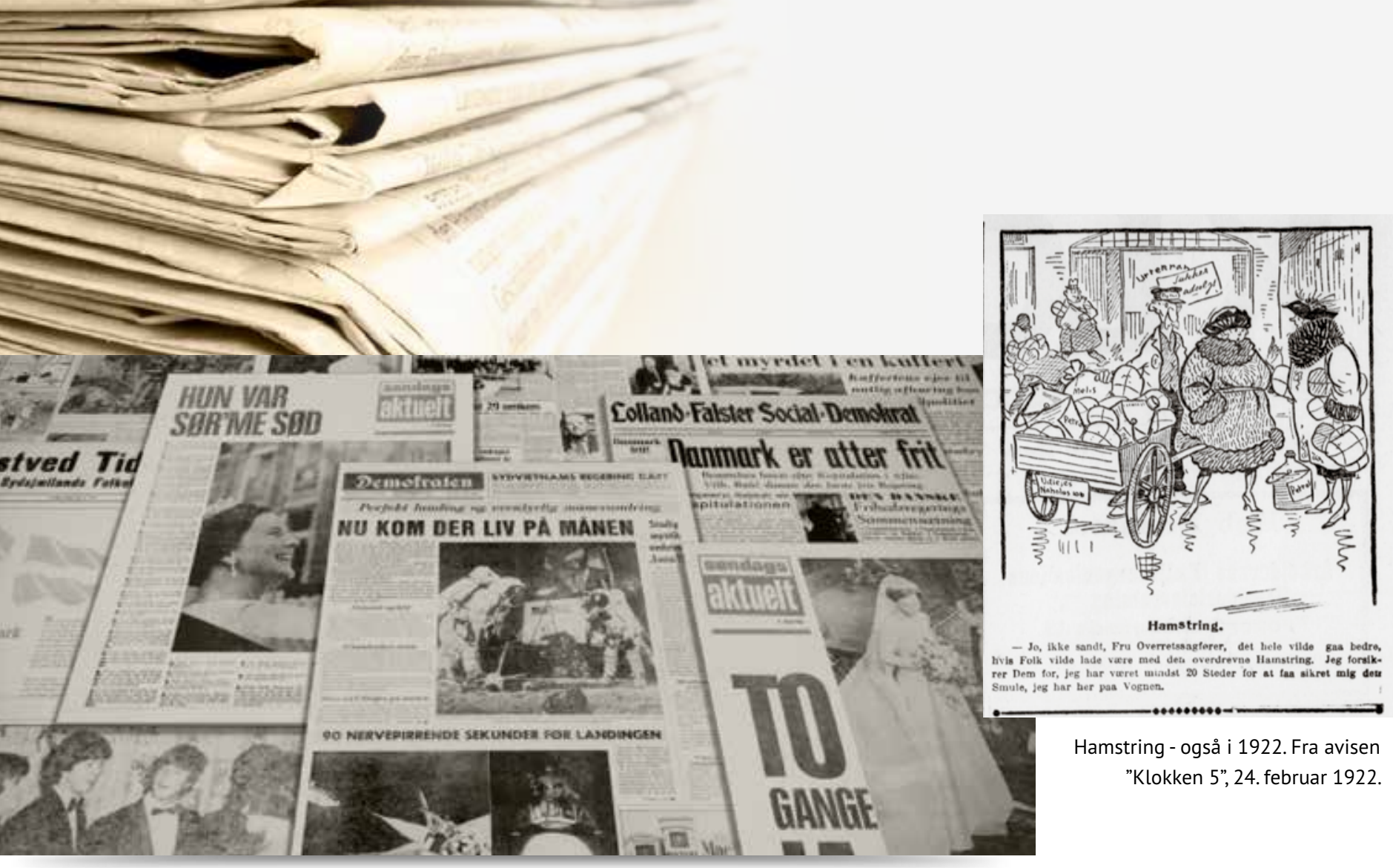

\title{
Fri adgang til seks millioner digitaliserede avissider
}

\author{
Aftale om åben online adgang til blandt såkaldte \\ ejerløse aviser, der ikke længere udkommer.
}

I tæt samarbejde med rettighedshaverne er der ekstraordinært blevet åbnet for online adgang til 67 digitaliserede avistitler udgivet i perioden 1921-

2002 via Det Kgl. Biblioteks database Mediestream. Det drejer sig om bl.a. Aktuelt, Land og Folk, Nationaltidende, Aalborg Amtstidende, Fyns Venstreblad og mange andre. I alt mere end seks millioner avissider. Disse såkaldt ejerløse aviser udgør den del af den nationale avissamling, som fortsat er ophavsretligt beskyttet, men hvor bladhusene ikke længere eksisterer.

Det Kgl. Bibliotek har her indgået en aftale om adgang til aviserne med Copydan Tekst \& Node, som repræsenterer rettighedshaverne til de ejerløse aviser. Aftalen er kommet i stand på baggrund af folkebibliotekernes lukning for publikum i den aktuelle coronasituation, hvor brugerne af fol- kebibliotekerne ikke kan få adgang til aviserne på deres lokale bibliotek som normalt.

\section{En guldgrube for historiefolket}

Det Kgl. Bibliotek giver via Mediestream adgang til over 35 millioner digitaliserede avissider. Her har alle interesserede mulighed for at søge i fx dødsannoncer, reklamer og historiske avisdebatter og følge udviklingen i mediernes omtale af tidligere tiders aktuelle samfundstemaer.

For eksempel kan man finde svar på, hvordan aviserne har omtalt pandemier gennem de sidste 300 år. Den Spanske Syge, der stoppede sin hærgen i 1920, er omtalt utallige gange i tidens aviser, og både "karantæne" og "hamstring" blev debatteret dengang som nu. Alle aviser fra før 1921 er frit tilgængeligt online for alle, og når der
Af Nicola Ravden, Louise Ahrenfeldt, Niels Bønding og Ditte Laursen, Det Kgl. Bibliotek dila@kb.dk 
ikke er corona-lukket, er det muligt for alle at få adgang til de nyere aviser i det samlede aviskatalog, hvis man møder op på Det Kgl. Biblioteks betjeningssteder.

\section{Fri online adgang for alle}

Nogle universiteter (CBS, KU, RUC, SDU) har i forvejen en licensaftale med Det Kgl. Bibliotek, der giver online adgang til de ejerløse aviser, men lige nu er der altså fri online adgang for alle.
Når folkebibliotekerne åbner igen, skal man som universitet igen have en licensaftale med Det Kgl. Bibliotek for at få online adgang til disse aviser.

Universiteter, som har interesse i en fremtidig online adgang til de ejerløse aviser, kan henvende sig til Det Kgl. Bibliotek.
9 Det Kgl. Bibliotek giver via Mediestream
adgang til over
35 millioner
digitaliserede
avissider.

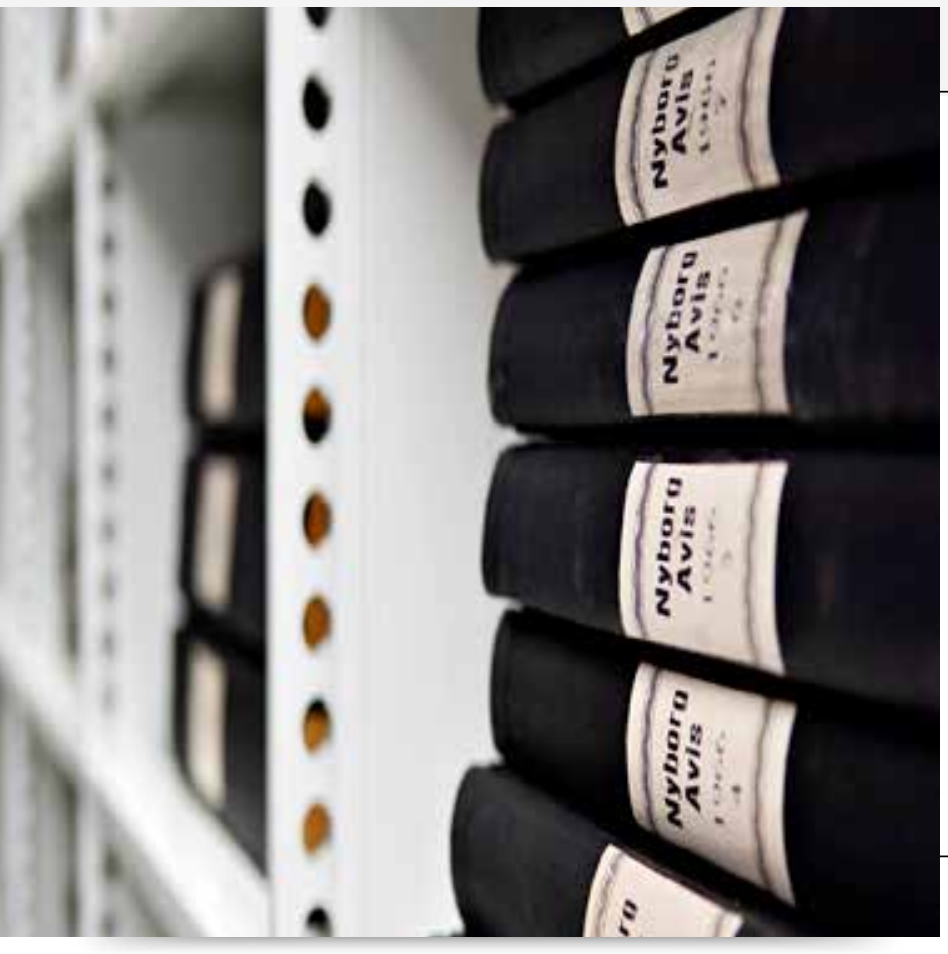

Foto: KB

\section{Projekt for avisdigitalisering 2014-17}

Ved en særlig bevilling på finansloven blev 35 millioner avissider, fordelt på 181 titler, digitaliseret i årene 2014-17 og gjort tilgængelige i mediestream.dk.

Digitaliseringsgrundlaget var mikrofilm. Udvælgelsen af aviser til digitalisering skete ud fra flere kriterier:

- De nulevende aviser blev prioriteret højest

- Komplet filmede titler blev prioriteret højere end ukomplet filmede

- Jævn geografisk dækning af hele landet

- Hele det politiske spektrum repræsenteret

\section{Visualisér danmarkshistorien - og download den som pdf.}

Med værktøjet Smurf kan man få visualiseret søgninger i aviserne over tid og på den måde spotte tidens tendenser - hvornår blev ordet "feminist" for eksempel mere moderne end "rødstrømpe" - og hvad var betegnelsen mon før 1970? Smurf er et godt analyse redskab, som kan være nyttigt for mange studerende.

http://labs.statsbiblioteket.dk/smurf

\section{mediestream.dk}

https://www.kb.dk/find-materiale/samlinger/statens-avissamling Kontakt@kb.dk

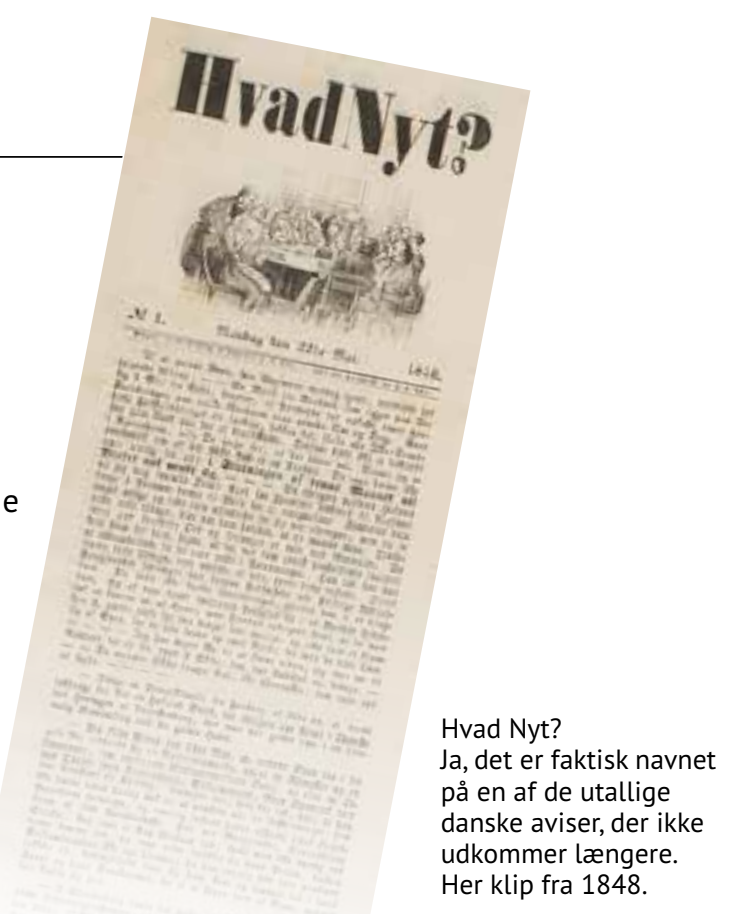

